\title{
Pengembangan Pemanfaatan Pengolahan Air Dalam Upaya Pemenuhan Kebutuhan Air di Dusun Temuireng, Desa Girisuko, Panggang, Gunungkidul
}

\author{
Developing the Utilization of Water Treatment Technology to \\ Fill Water Demand at Temuireng-Girisuko Village, \\ Panggang, Gunungkidul
}

\author{
Bambang Sugiarto $1^{\mathrm{a}^{*}}$, Suharwanto $2^{\mathrm{b}}$ \\ ${ }^{a}$ Teknik Kimia, Universitas Pembangunan Nasional "Veteran” Yogyakarta, 5528, Indonesia \\ ${ }^{b}$ Teknik Lingkungan, Universitas Pembangunan Nasional “Veteran” Yogyakarta, 55283Indonesia
}

\section{Artikel histori :}

Diterima Oktober 2017

Diterima dalam revisi November 2017 Diterima November 2017

Online Deseber 2017

\begin{abstract}
ABSTRAK: Air merupakan kebutuhan penting bagi hajat hidup warga di Kabupaten Gunung Kidul, Daerah Istimewa Yogyakarta. Temuireng merupakan salah satu desa di kecamatan Panggang, Kabupaten Gunung kidul, yang kebutuhan airnya masih jauh dari cukup. Di desa ini terdapat 269 kepala keluarga dengan rata-rata 4 jiwa di setiap kepala keluarga, sehingga terdapat kurang lebih 1076 jiwa yang kebutuhan airnya masih belum terpenuhi. Air untuk suplai ke desa ini terkendala oleh kemampuan pemompaan dan kualitas air baku. Kualitas air baku dimusim curah hujan tinggi yang berasal dari Baron maupun gua Ngobaran masih mengandung bakteri E-Coli 9000 per $100 \mathrm{ml}$ sedang total bakteri Coliform 28000 per $100 \mathrm{mt}$. Dari analisa air dimusim curah hujan sedang total coliform 4000 per $100 \mathrm{ml}$, dan analisa air dimusim curah hujan rendah (kemarau) total coliform berkisar 400 per $100 \mathrm{ml}$. Dari persyaratan maksimum 50 per $100 \mathrm{ml}$. Material terjerap dalam media karst saling berkaitan, antara bahan organik (parameter coliform) dan anorganik (parameter TDS). Dengan proses pengolahan secara laboratorium yang melibatkan proses flokulasi, sedimentasi, untuk dosis tawas, PAC dan biji Kelor sebesar 0,5 - 1 ppm mampu menurunkan TDS dari kisaran 262-288 ppm menjadi dibawah 200 ppm, dan jika dilanjutkan dengan filtrasi dengan media filter zeolit mampu menurunkan TDS hingga dibawah 180 ppm dalam waktu pengendapan 30 menit. Dan untuk dosis kelor jika dilanjutkan dengan perlakuan filter karbon mampu menurunkan TDS hingga dibawah $160 \mathrm{ppm}$ dalam waktu filtrasi 30-60 menit. Sedang untuk proses olahan dengan destilasi percik tenaga surya, dimungkinkan terjadi penurunan TDS maupun coliform namun diperlukan intensitas sinar matahari yang cukup tinggi untuk proses penguapan.

Kata Kunci: air; coliform; flokulsi-sedimentasi; saringan pasir lambat; distalasi percik tenaga surya
\end{abstract}

\begin{abstract}
Water is an important resource for the people in Gunung Kidul Regency, Special Region of Yogyakarta, Indonesia. Water scarcity is one of big issue in Temuireng, one of panggang's district in the Gunung Kidul regency. There is 269 family living in this villge and every family consist of four person so there are approximately 1076 person who need the clean water. The clean water supply for this village constrained by pump power and raw water quality. Raw water quality in rainy season (high rainfall intensity) contains of E-Coli 9000 per $100 \mathrm{ml}$ and total Coliform bacteri 28000 per $100 \mathrm{ml}$. Raw water quality in medium rainfall intensity season contains of total Coliform 4000 per $100 \mathrm{ml}$ and raw water quality in summer season (low rainfall intensity) contains of total Coliform 400 per $100 \mathrm{ml}$, from maximum regulation 50 per $100 \mathrm{ml}$. Material absorbed in karst include organic (coliform parameter) and anorganic (TDS parameter), which related in each other, can contaminate the water. Flocculation and sedimentation using 0.5-1 ppm doses of alum, PAC and kelor are performed to purify the water. The coagulant can decrease TDS parameter from 262-288 ppm to under $200 \mathrm{ppm}$, and if this process continued with filtration (filter zeolit), it can decrease TDS parameter to under $180 \mathrm{ppm}$ in 30 minute. If the process continued by filtration process (carbon filter) using kelor, it can decrease TDS parameter to under 160ppm in 30-60 minute. Using spark destilation solar energy process can decrease TDS parameter and coliform bacteria, but this process need high sunlight intensity for evaporation.
\end{abstract}

Keywords : water; coliform,flculations-sedimentations;, low sandfilter; splash distillation

*Corresponding Author: +6281225727255

Email: bgiartokd@gmail.com 
Citasi: Bambang Sugiarto, Suharwanto, 2017, Pengembangan Pemanfaatan Pengolahan Air Dalam Upaya Pemenuhan Kebutuhan Air di Dusun Temuireng, Desa Girisuko, Panggang, Gunungkidul, Eksergi, 14(2), 40-52

\section{Pendahuluan}

Air merupakan kebutuhan utama dimana pemanfatannya semakin meningkat dari waktu ke waktu. Seiring meningkatnya perekonomian masyarakat konsumsi air juga semakin meningkat. Kelangkaan air dapat menyebabkan terganggunya kehidupan makhluk hidup itu sendiri (USGS, 2010). Di beberapa daerah di dunia terdapat daerah daerah yang mengalami kelangkaan air bersih, khususnya di Negara berkembang (IWRM, 2009). Salah satu contohnya terjadi di Gunungkidul, Daerah Istimewa Yogyakarta, Indonesia, di daerah tersebut sulit diperoleh air (Evani, 2004).

Daerah Gunungkidul sebagai daerah dengan topografi karst yang terbentuk dari proses pelarutan batu gamping. Daerah tersebut sebagai bagian dari Pegunungan Sewu dimana Formasi Karst terdiri dari batuan karbonat dengan kelarutan dan laju infiltrasi yang tinggi. Air hujan yang jatuh di permukaan akan langsung meresap kedalam tanah dan membentuk sungai-sungai bawah tanah. Hal ini menyebabkan sulitnya mendapatkan air bersih di permukaan terutama pada musim kemarau. Namun demikian karakteristik batuan karst yang unik, ketersediaan air bawah tanah sangat berlimpah dengan kualitas air yang baik di musim kemarau dan berangsur menurun di musim penghujan (Nestmann dkk, 2011)

Penurunan kualitas air bawah tanah tersebut disebabkan oleh terbawanya material dari permukaan ke sungai bawah tanah melalui ponor-ponor yang ada sehingga menyebabkan kekeruhan, bakteri $E$. coli dan Total Coliform meningkat. Air Goa Ngobaran ternyata mengandung bakteri E. coli 9000 per $100 \mathrm{ml}$ sedang total bakteri Coliform 28000 per $100 \mathrm{ml}$ sampel.

Metode penyaringan dengan sistem saringan pasir lambat sebagai sistem yang tepat untuk daerah Gnungkidul. Sistem ini dipilih dengan pertimbangan efektifitas pengolahan, biaya dan kemudahan pengoperasiannya. Silva (2010) dalam penelitiannya membuktikan dapat menurunkan kekeruhan 99 \%. Selain itu Yogafany (2011) juga membuktikan dengan sistem saringan pasir lambat kandungan bakteri Total Coliform menurun hingga 99,998\% dan E. coli menurun hingga 99,999\%.2.

Air adalah zat cair yang tidak mempunyai rasa, warna, dan bau yang terdiri dari hydrogen dan oksigen dengan rumus kimia $\mathrm{H}_{2} \mathrm{O}$, karena air merupakan suatu larutan yang bersifat universal, merupakan zat yang paling alamiah maupun produk manusia hingga tingkat tertentu terlarut di dalamnya. Dengan demikian di dalam air mengandung zatzat terlarut. Zat-zat ini sering disebut pencemar yang terdapat dalam air (Linsley,1991). Air adalah istilah yang menggambarkan kesesuaian atau kecocokan air untuk penggunaan tertentu, misalnya air minum, perikanan, industri, rekreasi dan sebagainya.

Parameter kualitas air bersih ataupun air minum yang ditetapkan dalam keputusan Menteri Kesehatan Nomor : 492/Permenkes/IV/2010 terdiri dari parameter fisik, kimia, parameter radioaktif, dan parameter mikrobiologi.

\begin{tabular}{|c|c|c|c|}
\hline No & Jenis Parameter & Satuan & $\begin{array}{l}\text { Kadar maksimum } \\
\text { yang diperbolehkan }\end{array}$ \\
\hline \multirow[t]{13}{*}{1} & $\begin{array}{l}\text { Parameter yang berhubungan } \\
\text { langsung dengan kesehatan }\end{array}$ & & \\
\hline & a. Parameter Mikrobiologi & & \\
\hline & 1) E.Coli & $\begin{array}{l}\text { Jumlah per } \\
100 \mathrm{ml} \text { sampel }\end{array}$ & 0 \\
\hline & 2) Total Bakteri Koliform & $\begin{array}{l}\text { Jumlah per } \\
100 \mathrm{ml} \text { sampel }\end{array}$ & 0 \\
\hline & b.Kimia an-organik & & \\
\hline & 1) Arsen & $\mathrm{mg} / \mathrm{l}$ & 0,01 \\
\hline & 2) Fluorida & $\mathrm{mg} / \mathrm{l}$ & 1,5 \\
\hline & 3) Total Kromium & $\mathrm{mg} / \mathrm{l}$ & 0,05 \\
\hline & 4) Kadmium & $\mathrm{mg} / \mathrm{l}$ & 0,003 \\
\hline & 5) Nitrit, (Sebagai $\mathrm{NO}_{2}^{-}$) & $\mathrm{mg} / \mathrm{l}$ & 3 \\
\hline & 6) Nitrat, (Sebagai $\mathrm{NO}_{3}{ }^{-}$) & $\mathrm{mg} / \mathrm{l}$ & 50 \\
\hline & 7) Sianida & $\mathrm{mg} / \mathrm{l}$ & 0,07 \\
\hline & 8) Selenium & $\mathrm{mg} / \mathrm{l}$ & 0,01 \\
\hline \multirow[t]{15}{*}{2} & $\begin{array}{l}\text { Parameter yang tidak langsung } \\
\text { berhubungan dengan kesehatan }\end{array}$ & & \\
\hline & a.Parameter Fisik & & \\
\hline & 1) Bau & & Tidak berbau \\
\hline & 2) Warna & TCU & 15 \\
\hline & 3)Total zat padat terlarut (TDS) & $\mathrm{mg} / \mathrm{l}$ & 500 \\
\hline & 4) Kekeruhan & NTU & 5 \\
\hline & 5) Rasa & & Tidak berasa \\
\hline & 6) Suhu & $\square \mathrm{C}$ & suhu udara \pm 3 \\
\hline & b.Parameter Kimiawi & & \\
\hline & 1) Aluminium & $\mathrm{mg} / \mathrm{l}$ & 0,2 \\
\hline & 2) Besi & $\mathrm{mg} / \mathrm{l}$ & 0,3 \\
\hline & 3) Kesadahan & $\mathrm{mg} / \mathrm{l}$ & 500 \\
\hline & 4) Khlorida & $\mathrm{mg} / 1$ & 250 \\
\hline & 5) Mangan & $\mathrm{mg} / \mathrm{l}$ & 0,4 \\
\hline & 6) $\mathrm{pH}$ & & $6,5-8,5$ \\
\hline
\end{tabular}

\begin{tabular}{|l|l|c|c|}
\hline No & \multicolumn{1}{|c|}{ Jenis Parameter } & Satuan & $\begin{array}{c}\text { Kadar maksimum } \\
\text { yang diperbolehkan }\end{array}$ \\
\hline & 7) Seng & $\mathrm{mg} / 1$ & 3 \\
\hline & 8) Sulfat & $\mathrm{mg} / 1$ & 250 \\
\hline & 9) Tembaga & $\mathrm{mg} / 1$ & 2 \\
\hline & 10) Amonia & $\mathrm{mg} / 1$ & 1,5 \\
\hline
\end{tabular}

Gambar 1. Parameter kualitas air bersih ataupun air minum yang ditetapkan dalam keputusan Menteri Kesehatan Nomor : 492/Permenkes/IV/2010

\subsection{Model Pengolahan Air Minum Pengendapan}

Pengendapan atau settling merupakan proses pemisahan partikel padat yang terlarut dalam air yang banyak dijumpai secara alamiah dalam danau atau telaga. Namun diperlukan waktu lama untuk memberi kesempatan partikel mengendap secara sempurna. Untuk mempercepat proses pengendapan partikel dalam air seringkali dikombinasikan dengan proses kimiawi. Namun dengan pertimbangan pengaruh bahan kimia yang digunakan terhadap komposisi air olahan dan limbah kimia yang mungkin terbentuk serta proses yang tidak sederhana maka dipilih bahan pengendap yang bersahabat dengan alam dan ramah lingkungan. Jika kadar e-coli cukup signifikan maka digunakan tawas, serbuk biji kelor dan gas chlor atau kaporit. 
II. PARAMETER TAMBAHAN

\begin{tabular}{|c|c|c|c|}
\hline No & Jenis Parameter & Satuan & $\begin{array}{c}\text { Kadar maksimum } \\
\text { yang diperbolehkan }\end{array}$ \\
\hline 1. & KIMIAWI & & \\
\hline \multirow[t]{10}{*}{ a. } & Bahan Anorganik & & \\
\hline & Air Raksa & $\mathrm{mg} / 1$ & 0,001 \\
\hline & Antimon & $\mathrm{mg} / \mathrm{l}$ & 0,02 \\
\hline & Barium & $\mathrm{mg} / 1$ & 0,7 \\
\hline & Boron & $\mathrm{mg} / \mathrm{l}$ & 0,5 \\
\hline & Molybdenum & $\mathrm{mg} / \mathrm{l}$ & 0,07 \\
\hline & Nikel & $\mathrm{mg} / 1$ & 0,07 \\
\hline & Sodium & $\mathrm{mg} / \mathrm{l}$ & 200 \\
\hline & Timbal & $\mathrm{mg} / \mathrm{l}$ & 0,01 \\
\hline & Uranium & $\mathrm{mg} / 1$ & 0,015 \\
\hline \multirow[t]{25}{*}{ b. } & Bahan Organik & & \\
\hline & Zat Organik $\left(\mathrm{KMnO}_{4}\right)$ & $\mathrm{mg} / 1$ & 10 \\
\hline & Deterjen & $\mathrm{mg} / \mathrm{l}$ & 0,05 \\
\hline & Chlorinated alkanes & & \\
\hline & Carbon tetrachloride & $\mathrm{mg} / 1$ & 0,004 \\
\hline & Dichloromethane & $\mathrm{mg} / 1$ & 0,02 \\
\hline & 1,2-Dichloroethane & $\mathrm{mg} / \mathrm{l}$ & 0,05 \\
\hline & Chlorinated ethenes & & \\
\hline & 1,2-Dichloroethene & $\mathrm{mg} / 1$ & 0,05 \\
\hline & Trichloroethene & $\mathrm{mg} / \mathrm{l}$ & 0,02 \\
\hline & Tetrachloroethene & $\mathrm{mg} / 1$ & 0,04 \\
\hline & Aromatic hydrocarbons & & \\
\hline & Benzene & $\mathrm{mg} / 1$ & 0,01 \\
\hline & Toluene & $\mathrm{mg} / 1$ & 0,7 \\
\hline & Xylenes & $\mathrm{mg} / \mathrm{l}$ & 0,5 \\
\hline & Ethylbenzene & $\mathrm{mg} / 1$ & 0,3 \\
\hline & Styrene & $\mathrm{mg} / 1$ & 0,02 \\
\hline & Chlorinated benzenes & & \\
\hline & 1,2-Dichlorobenzene (1,2-DCB) & $\mathrm{mg} / \mathrm{l}$ & 1 \\
\hline & 1,4-Dichlorobenzene (1,4-DCB) & $\mathrm{mg} / 1$ & 0,3 \\
\hline & Lain-lain & & \\
\hline & Di(2-ethylhexyl)phthalate & $\mathrm{mg} / 1$ & 0,008 \\
\hline & Acrylamide & $\mathrm{mg} / 1$ & 0,0005 \\
\hline & Epichlorohydrin & $\mathrm{mg} / \mathrm{l}$ & 0,0004 \\
\hline & Hexachlorobutadiene & $\mathrm{mg} / \mathrm{l}$ & 0,0006 \\
\hline
\end{tabular}

Gambar 2. Parameter tambahan kualitas air bersih ataupun air minum yang ditetapkan dalam keputusan Menteri Kesehatan Nomor : 492/Permenkes/IV/2010

\section{Reaksi Aluminium Sulfat dengan kalsium bikarbonat}

dalam air :

$$
\begin{aligned}
& \mathrm{Al}_{2}\left(\mathrm{SO}_{4}\right)_{3} .18 \mathrm{H}_{2} \mathrm{O}+ \\
& \mathrm{Ca} 3 \mathrm{Ca}\left(\mathrm{HCO}_{3}\right)_{2} \\
& \longrightarrow \quad 2 \mathrm{Al}(\mathrm{OH})_{3}+3 \mathrm{CaSO}_{4}+6 \mathrm{CO}_{2} \\
& +18 \mathrm{H}_{2} \mathrm{O}
\end{aligned}
$$

Tetapi jika e-coli mendekati 0 dan yang dominan adalah partikel halus dari karbonat, bikarbonat, kalsit, silikat dan magnesit, dipilih $\mathrm{CaO}$ atau semen. Dengan target partikel halus, sedikit e-coli dapat terjerap dalam cross link agent yang terbentuk oleh $\mathrm{CaO}$ atau semen yang ditebarkan dan mengendap bersama-sama pada bagian bawah bak penampung.

Pengendapan yang dipercepat dengan menambahkan bahan kimia disebut koagulasi yaitu merupakan suatu peristiwa penggabungan partikel-partikel yang telah mengalami proses destabilisasi dengan penambahan bahan kimia sehingga terbentuk partikel dengan ukuran lebih besar yang mudah untuk diendapkan.

Pengadukan awal merupakan pemberian energi agar terjadi tumbukan antar partikel tersuspensi dan koloid agar terbentuk gumpalan sehingga dapat dipisahkan melalui proses pengendapan lanjut dan penyaringan dan untuk mempercepat dan menyeragamkan penyebaran zat kimia melalui air yang diolah.

\section{Saringan Pasir Lambat}

Slow Sand Filtration merupakan sebuah metode penyaringan untuk menghasilkan air bersih, dikenal sejak tahun 1804. Pertamakali dibuat dan didisain oleh John Gibb di Skotlandia dan dia berhasil menjual air hasil saringannya ke masyarakat umum dengan harga yang sangat murah per gallon nya. Tahun 1829 James Simpson membangun instalasi pengolahan air untuk penyediaan air di London dengan mengadaptasi metode saringan pasir lambat. Selanjutnya di tahun 1852 semenjak metode tersebut menjadi sangat dikenal dan dirancang dengan baik, slow snd filtration sebagai metode penyaringan mekanik yang menyaring partikel-partikel terlarut sehingga dapat menurunkan tingkat kekeruhan air. Keberadaan bakteri pathogen dan kemampuan slow sand filtration untuk menghilangkannya benar benar tidak diketahui pada waktu itu (Huisman \& wood, 1974).

Saringan Pasir Lambat mungkin dapat menjadi proses pengolahan air yang paling ekonomis, sederhana, dan terpercaya untuk mendapatkan air bersih. Proses ini berbeda dari saringan pasir cepat terutama pada laju filtrasi yang diterapkan. Saringan pasir lambat adalah proses pengolahan air yang memungkinkan air baku meresap dari permukaan melalui media pasir halus yang selanjutnya keluar melalui saluran keluaran dibagian bawah. Ukuran butir efektif (d10) yang digunakan pada system ini lebih halus dari pada saringan pasir cepat, biasanya ukuran butir efektif adalah kisaran 0,15- 0,30 mm dengan koefisien keseragaman $(\mathrm{Cu})$ kurang dari 5 dan sebaiknya kurang dari 3 seperti yang disebutkan pada table 1.1 (Visscher, 1990). Ukuran butir yang kecil ini memberikan celah yang sangat kecil pada filter diantara butir yang memungkinkan air untuk mengalir dengan perlahan melalui media

\begin{tabular}{|c|c|}
\hline Design criteria & Recommended value \\
\hline Design period & $10-15$ years \\
\hline Period of operation & $24 \mathrm{~h} / \mathrm{d}$ \\
\hline Filtration rate & $0,1-0,2 \mathrm{~m} / \mathrm{h}$ \\
\hline Filter bed area & $\begin{array}{l}5-200 \mathrm{~m} 2 * \text { per filter, } \\
\text { minimum of } 2 \text { unit }\end{array}$ \\
\hline Height of filter bed & \\
\hline Initial & $0,8-0,9 \mathrm{~m}$ \\
\hline $\begin{array}{l}\text { Final before resanding } \\
\text { Sand characteristhics }\end{array}$ & $0,5-0,6 \mathrm{~m}$ \\
\hline Effective size $\mathrm{d} 10$ & $0,15-0,30 \mathrm{~mm}$ \\
\hline $\begin{array}{l}\text { Uniformity coefficient } \\
\mathrm{Cu}\end{array}$ & $\begin{array}{l}<5 \text {, preferably below } 0,30 \\
\mathrm{~mm}\end{array}$ \\
\hline $\begin{array}{l}\text { Height of underdrains } \\
\text { including gravel layer }\end{array}$ & $0,3-0,5 \mathrm{~m}$ \\
\hline $\begin{array}{l}\text { Height of supernatant } \\
\text { water }\end{array}$ & $1 \mathrm{~m}$ \\
\hline
\end{tabular}
penyaringan, laju filtrasi biasanya antara $0,1-0,2 \mathrm{~m} / \mathrm{h}$ (Visscher, 1990).

Tabel 1. Kriteria Desain untuk slow sand filter

Padatan tersuspensi, materi koloid, dan bakteri dari air baku yang terakumulasi pada lapisan paling atas yang tidak dibersihkan secara teratur, menjadikan bakteri yang melakukan pemurniaan berkembang dan memainkan peran 
paling penting pada proses saringan pasir lambat untuk menghasilkan kualitas air yang baik. Ini adalah alasan mengapa saringan pasir lambat disebut juga filtrasi biologi (Huisman \&Wood, 1974)

\section{Spray Distilation Energy Surya}

Distilasi merupakan proses pemisahan komponen berdasar keseimbangan fase dan penguapan dengan memanfaatkan driving force, panas. Penguapan air/difusi air ke udara dipengaruhi oleh beberapa faktor, diantaranya : luas permukaan, perbedaan konsentrasi, perbedaan tekanan dan keberadaan kalor/panas.

Perpindahan massa air ke udara:

Panas yang diperlukan untuk penguapan sebesar $\mathrm{N}_{\mathrm{A}}$

$$
\begin{aligned}
& N_{A}=k_{Y}\left(Y_{A}-Y_{u}\right) \\
& \mathrm{Q}=\mathrm{N}_{\mathrm{A}} \cdot \lambda_{\mathrm{A}}
\end{aligned}
$$

Panas dipenuhi oleh panas radiasi mata hari pada sistem rumah kaca. Panas yang ditransfer penyerap ke Air

$$
\begin{aligned}
& Q_{R}=A \cdot \sigma\left(T_{B}^{4}\right) \\
& Q=A . \sigma\left(T_{B}^{4}-T_{A}^{4}\right)
\end{aligned}
$$

$\mathrm{T}_{\mathrm{B}}$ dipengaruhi oleh intensitas sinar surya

Panas yang ditransfer ke air dari penyerap panas pada kondisi intensitas sinar tinggi Q lebih besar dari kebutuhan, sehingga kelebihan panas dimaksud akan disimpan dan akan digunakan pada saat intensitas menurun (sore atau malam hari).

Proses Pengembunan uap air : Udara dalam sistem, mencapai kondisi kelembaban jenuh. Pada kondisi ini bila terjadi penambahan 1 mol uap air akan diikuti pengembunan 1 mol air, dan sebaliknya apabila terembunkan 1 mol air akan diikuti kecenderungan penguapan $1 \mathrm{~mol}$ air.(disebut kondisi setimbang).

Proses pengembunan dapat terjadi karena udara yang jenuh dengan uap air akan menabrak kaca sehingga kehilangan energi kinetik, energi tersebut diambil dari uap air itu sendiri sehingga akan terjadi pengembunan. Proses pengembunan dapat juga dibuat secara paksa dengan proses pendinginan dalam kondensor.

Pada proses ini spray berfungsi untuk memperluas bidang kontak butiran air dengan lingkungan sistem yang dipanaskan dengan bantuan sinar matahari melalui material transparan seperti kaca atau acrylic.

\subsection{Tujuan dari penelitian ini adalah :}

a. Implementasi Prototype pengolahan air yang merupakan gabungan dari: Pengendapan alamiah dengan penambahan bahan pengendap ramah lingkungan, dan Saringan Pasir Lambat.

b. Melakukan optimasi pada : i. Penentuan dosis bahan pengendap (PAC, tawas dan serbuk kelor) dengan variabel waktu, kadar/dosis bahan penendap terhadap parameter TDS dari partikel terlarut

ii. Pengaruh tinggi bed saringan pasir terhadap parameter TDS dari partikel terlarut

iii. Pengaruh dosis dan tinggi bed saringan pasir terhadap e-coli dan total coliform, pada kondisi optimum

\section{Metode Penelitian}

Partikel karst yang terinfiltrasi dalam air bawah tanah, mengandung $\mathrm{Ca}$ dan $\mathrm{Mg}$ yang merupakan komponen pegotor yang tidak dikehendaki, sehingga batu kapur, PCA maupun tawas dapat dipakai sebagai penjerap partikel halus yang berasal dari infiltrasi kikisan karst tersebut, namun perlu dosis yang tepat dan ini akan dikaji dalam penelitian awal. Setelah proses flokulasi dilakukan pemisahan partikel dengan pengendapan. Proses ini dilanjutkan dengan filtrasi pada sistem saringan lambat.

Jika kandungan e-coli dan total coliform tinggi, maka diperlukan proses sterilisasi menggunakan bahan alami seperti serbuk biji kelor yang mempunyai kemampuan menurunkan e-coli dan total coliform, namun jika bahan ini tidak mampu maka dilakukan dengan kaporit, namun proses ini perlu disempurnakan dengan pengoperasian filter karbon aktif sehingga kelebihan khlor yang berasal dari kaporit bisa diturunkan.

Bila energi air cukup namun $\mathrm{pH}$ air diatas normal, menunjukkan adanya infiltrasi garam dan air laut saat laut mengalami pasang, teknologi sederhana, murah dan berdaya guna adalah distilasi percik tenaga surya, dengan memperluas bidang kontak (transfer masa) antara air dengan udara panas, maka diperlukan perancangan spray pada distilasi tenaga surya

Tahap yang dilakukan pada penelitian awal adalah sebagai berikut :

1. Pekerjaan awal laboratorium dan lapangan

Pekerjaan lapangan dilakukan dengan melakukan survey keberadaan sumber air bawah tanah, pengambilan contoh, analisa sifat fisik dan kimia air (uji laboratorium), melakukan pemetaan, dan memprediksi volume air. Survey sumber Zeolit, produsen sebagai media filter yang berada disekitar lokasi.

2. Perancangan prototype SPAM di Temuireng

Dari pertimbangan kajian pustaka, serta kemampuan sumber daya manusia yang tersedia untuk keperluan pengelolaan dan perawatan maka prototype yang akan dikembangkan seperti pada Gambar 3.

Implementasi dari rencana prototype diatas dikembangkan dalam model rancangan tataletak alat proses dari prototype pada Gambar 4. 


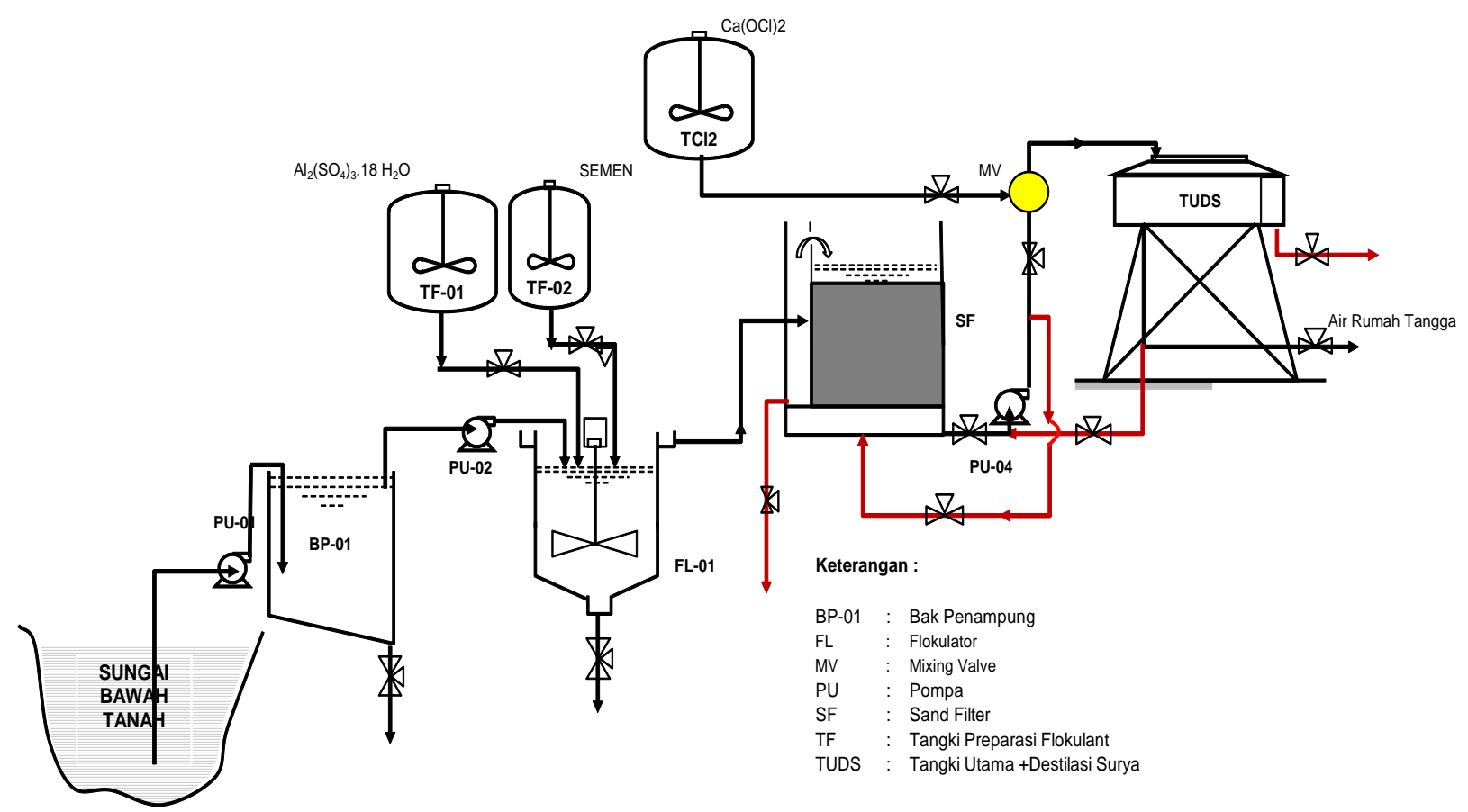

Gambar 3. Rencana Prototype Alat Pengolahan Air di Temuireng Paska Pempompaan

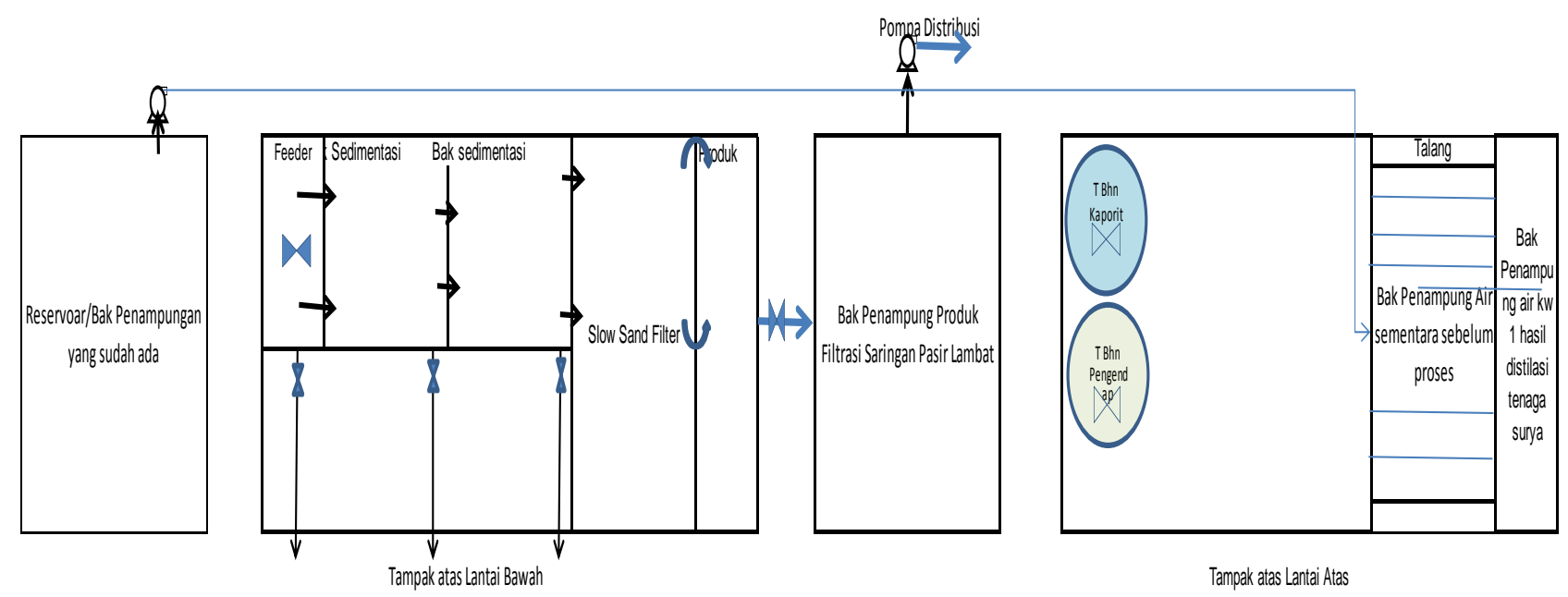

Gambar 4. Rancangan Tataletak Alat Proses Pengolahan Air di Temuireng

\section{Prototype alat skala Laboratorium}

Untuk uji pengolahan air diperlukan alat skala laboratorium, sehinggabisa dilakukan uji coba terhadap proses pengolahan air, baik secara flokulasi, pengendapan filtrasi maupun model distilasi percik.

Adapun unit alat skala laboratorium seperti tampak pada Gambar 5.

\section{Uraian Proses Pengolahan}

Air hasil pemompaan dari sumber air yang berasal dari pantai Baron dan atau goa Ngobaran dipompa secara bertahap hingga sampai ke lokasi Temuireng yang sudah ada. Dari tanki reservoar Temuireng air dialirkan ke unit pengolahan.

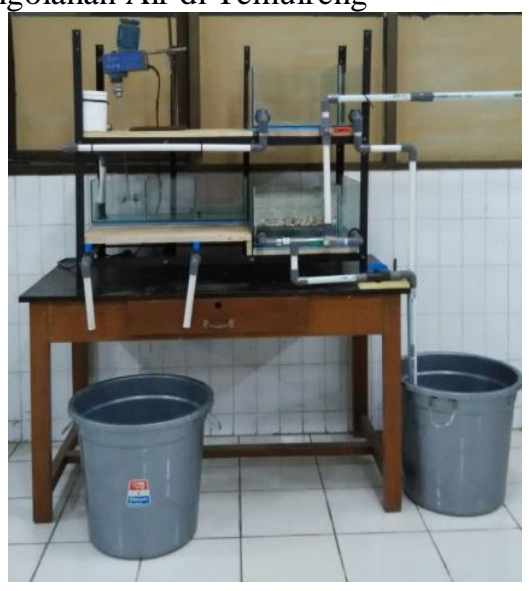

Gambar 5. Alat PAM skala laboratorium 
Mula-mula air dipompa ke bak penampung sementara di lantai atas sehingga proses bisa dioperasikan secara gravitas (untuk penghematan operasional cost). Selanjutnya dari bak sementara ini juga dialirkan menuju proses flokulasi untuk penurunkan kadar e-coli dan total coliform serta padatan terlarut menggunakan penggumpal alami (biji kelor atau tawas) dalam flokulator berpengaduk, disini jumlah ppm bahan koagulan ditentukan berdasar bahan yang akan diendapkan.

Selanjutnya air yang telah diproses dalam flokulator dialirkan overflow secara seri ke bak pengendap 1 dan 2 , untuk memberi kesempatan bahan mengendap dengan baik. Kemudian hasil pengendapan ini dialirkan secara overflow ke saringan pasir lambat, yang berisi bahan-bahan penyaring (zeolit dan arang) yang telah diaktivasi sebelumnya. Air produk olahan ini dianalisa lebih lanjut berdasar baku mutu, jika diperlukan (kandungan e-coli dan total coliform masih belum sesuai baku mutu) dilakukan klorinasi menggunakan kaporit pada bak penampung hasil filter sebelum ditampung pada bak distribusi. Namun jika sudah memenuhi syarat baku mutu, air bisa dialirkan menuju penampung akhir/distribusi, siap untuk didistribusi ke warga. Bak atas juga bisa digunakan sebagai penampung alternatif, aliran menuju bak ini menggunakan spray paralel sehingga memungkinkan air teruapkan, bak ini juga dilengkapi dengan penutup kaca/akrilik/poikarbonat, yang berfungsi sebagai suplai energi sinar matahari. Diharapkan air yang menguap dapat terembunkan dan mengalir kearah talang aliran embun menuju penampung kondensat (merupakan produk air distilasi percik tenaga surya yang merupakan produk samping dari proses ini). Perlu juga dianalisa secara periodik pada tanki-tanki penampung olahan, baik tanki produk 1 , produk 2 maupun produk 3 . Untuk kepastian kualitas produk

\section{Hasil dan Pembahasan}

Pada penelitian ini dilalkukan beberapa simulasi yaitu simulasi dosis koagulan, ketebalan sand filter dan carbon filter.

\subsection{Simulasi dosis koagulan}

Koagulan diujicobakan adalah tawas, PAC, dan biji kelor pada berbagai konsentrasi dan waktu pengendapan, dengan parameter TDS.

\section{a. Penentuan penggunaan dosis tawas optimum.}

Uji coba laboratorium dalam penggunaan tawas sebagai koagulan, diperoleh hasil uji secara grafis pada Gambar 6. Fenomena umum yang diperoleh dilihat dari grafik penggunaan dosis tawas 0,5 - 3,0 ppm nampak penurunan TDS hampir sama, jika diinginkan penurunan signifikan diperlukan dosis yang semakin tinggi dengan volume yang semakin besar, serta waktu yang semakin lama.

Berdasarkan karakter dosis tawas yang disajikan dalam grafik diatas maka dosis optimum penggunaan tawas adalah antara 0,5 - 1,0 ppm yang dapat menurunkan TDS sampai dibawah 200 ppm dalam waktu 30 menit.
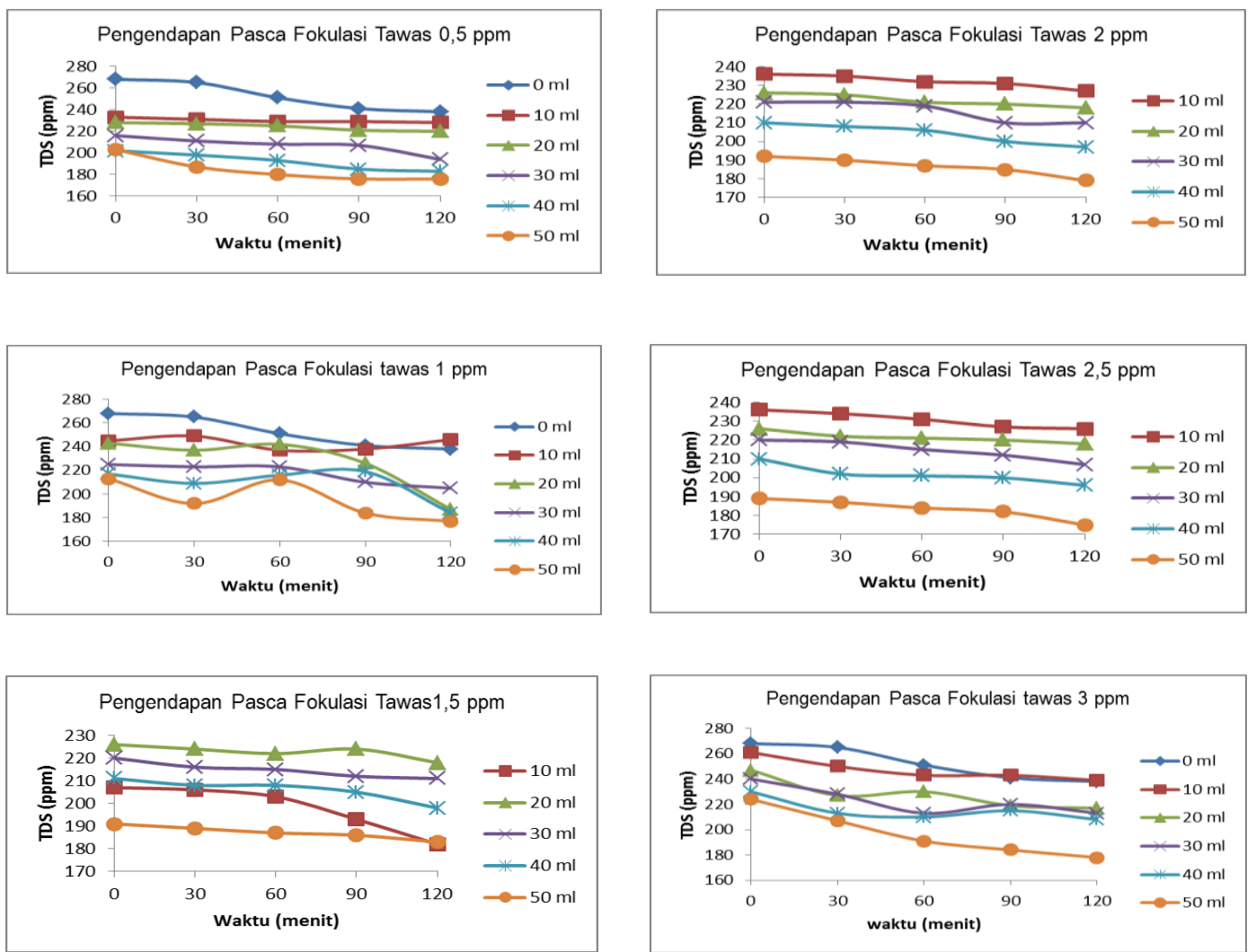

Gambar 6. Pengujian dosis tawas dengan parameter TDS dan Waktu Pengendapan 
Eksergi, Vol 14, No. 2. 2017

ISSN: $1410-394 \mathrm{X}$

\section{b. Penentuan penggunaan dosis PAC optimum.}
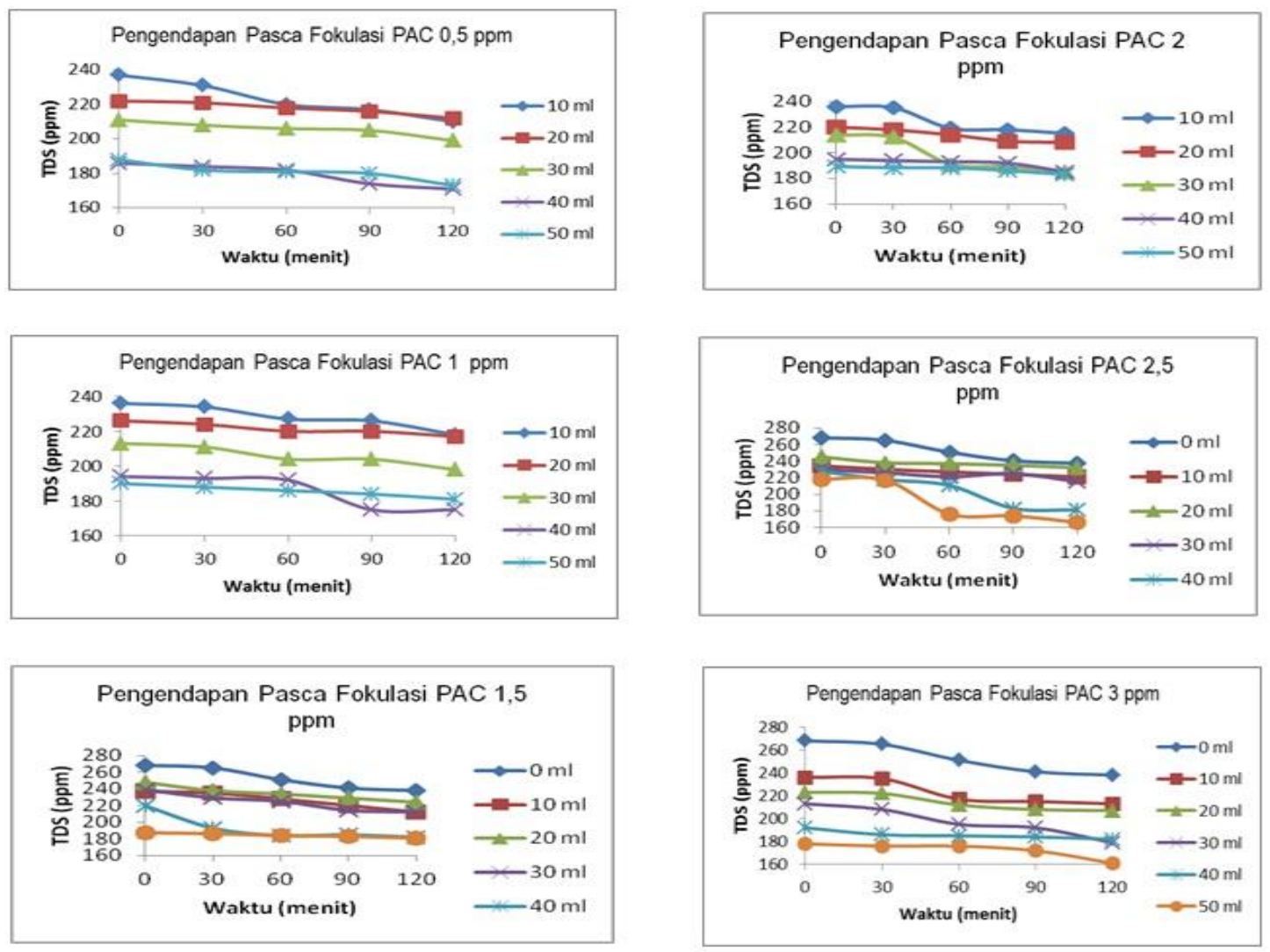

Gambar. 7. Pengujian dosis PAC dengan parameter TDS dan Waktu Pengendapan
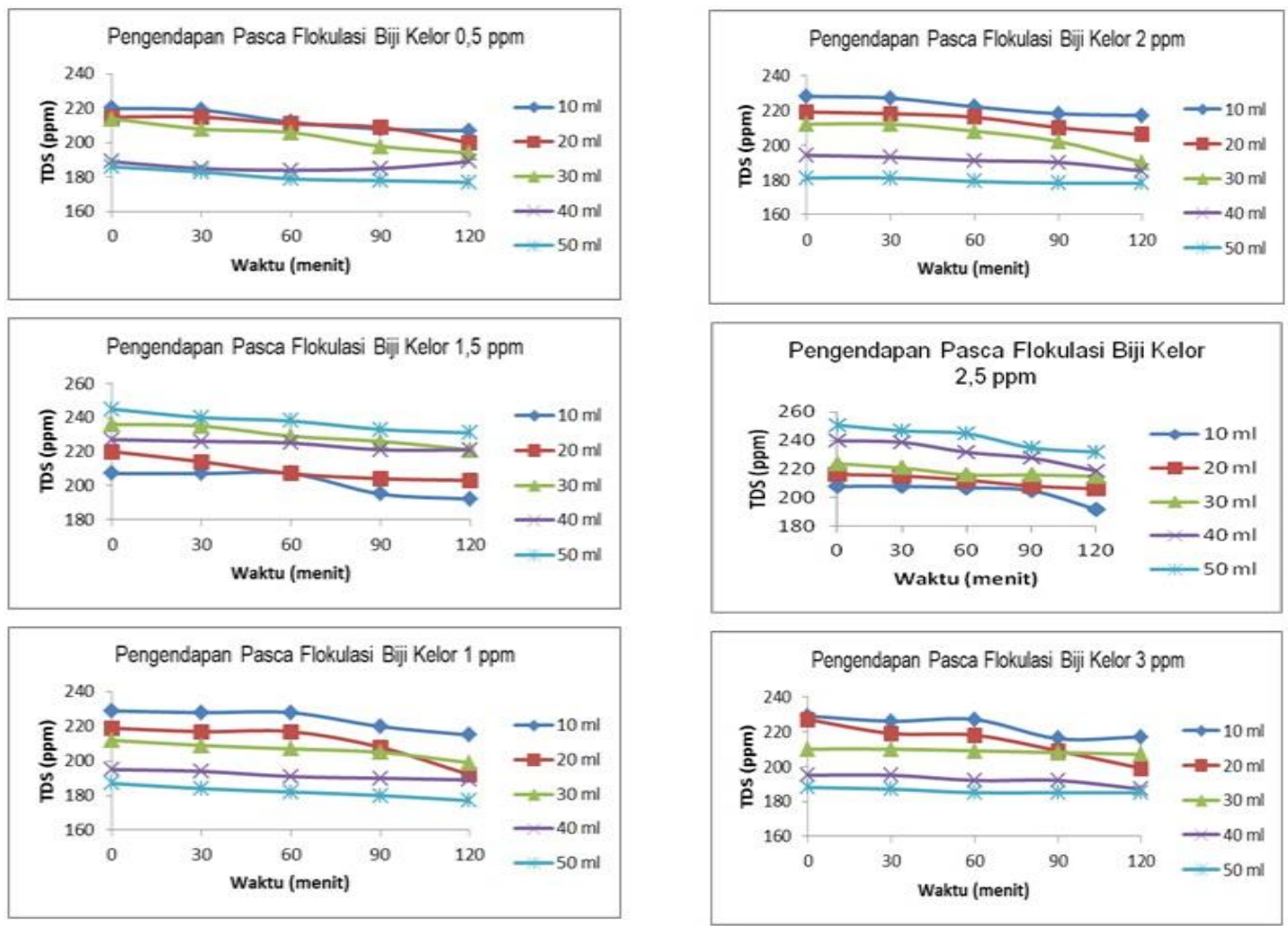

Gambar 8. Pengujian dosis serbuk biji kelor dengan parameter TDS dan Waktu Pengendapan 
Uji coba laboratorium dalam penggunaan PAC sebagai koagulan, diperoleh hasil uji secara grafis pada gambar 7 . Fenomena umum yang diperoleh dilihat dari grafik penggunaan dosis PAC 0,5 - 3,0 ppm nampak penurunan TDS hampir seragam, jika diinginkan penurunan signifikan diperlukan dosis yang semakin tinggi dengan volume yang semakin besar, serta waktu yang semakin lama. Berdasarkan karakter dosis PAC yang disajikan dalam grafik diatas maka dosis optimum penggunaan PAC adalah antara 0,5 - 1,5 ppm yang dapat menurunkan TDS sampai dibawah 200 ppm dalam waktu 60 menit.

\section{c. Penentuan penggunaan dosis biji kelor optimum.}

Uji coba laboratorium dalam penggunaan serbuk biji kelor sebagai koagulan, diperoleh hasil uji secara grafis sebagaimna tampak pada Gambar 8.

Fenomena umum yang diperoleh dilihat dari grafik penggunaan dosis serbuk biji kelor 0,5 - 3,0 ppm nampak penurunan TDS hampir seragam, jika diinginkan penurunan signifikan diperlukan dosis yang semakin tinggi dengan volume yang semakin besar, serta waktu yang semakin lama. Berdasarkan karakter dosis serbuk biji kelor yang disajikan dalam grafik diatas maka dosis optimum penggunaan serbuk biji kelor adalah antara 0,5 - 1,0 ppm yang dapat menurunkan TDS sampai dibawah $200 \mathrm{ppm}$ dalam waktu 30 menit. besar, serta waktu yang semakin lama. Berdasarkan karakter dosis serbuk biji kelor yang disajikan dalam grafik diatas maka dosis optimum penggunaan serbuk biji kelor adalah antara 0,5 - 1,0 ppm yang dapat menurunkan TDS sampai dibawah 200 ppm dalam waktu 30 menit.

Dari penggunaan ketiga koagulan yaitu Tawas, PAC dan Biji Kelor maka dapat dinyatakan ada kemiripan karakter penurunan TDS pada penggunaan koagulan Tawas dan Biji Kelor yang mampu menurunkan TDS hingga dibawah 200 ppm dalam waktu 30 menit

\subsection{Simulasi ketebalan sand filter}

Penentuan ketebalan bed (koral, zeolit sedang, zeolit halus), diperoleh hasil uji secara grafis sebagai berikut:

\section{a. Penentuan ketebalan filter dengan koagulan Tawas.}

Uji coba laboratorium dalam penggunaan tawas sebagai koagulan, diperoleh hasil uji secara grafis dalam penentuan ketebalan filter sebagai terlihat pada Gambar 9.

Fenomena umum yang dilihat dari grafik penentuan ketebalan filter dengan dosis tawas 0,5 - 3,0 ppm nampak penurunan TDS hampir sama, jika diinginkan penurunan signifikan diperlukan ketebalan filter zeolit yang semakin tebal, serta waktu yang semakin lama. Berdasarkan karakter dosis tawas yang disajikan dalam grafik diatas maka ketebalan optimum penggunaan filter zeolit pada ukuran 2,5 cm koral; 2,5 cm zeolit sedang dan 7,5 cm zeolit halus yang dapat menurunkan TDS sampai dibawah 180 ppm pada penggunaan tawas $0,5-1,0 \mathrm{ppm}$, dalam waktu 30 menit.
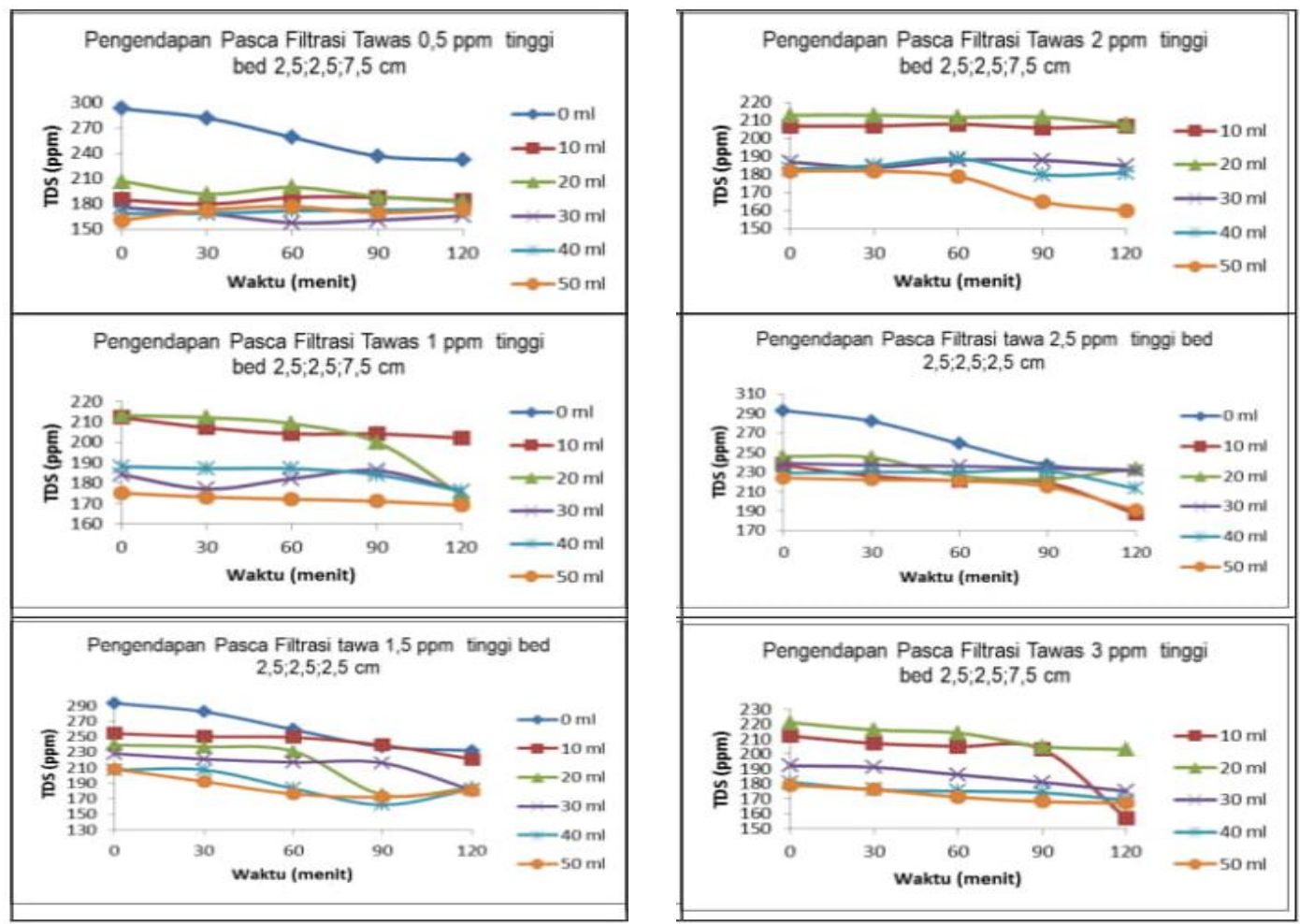

Gambar 9.. Penentuan tinggi optimum bed filter zeolite terhadap dosis tawas dengan parameter TDS dan Waktu Pengendapan 


\section{b. Penentuan ketebalan filter dengan koagulan PAC.}

Uji coba laboratorium dalam penggunaan PAC sebagai koagulan, diperoleh hasil uji secara grafis dalam penentuan ketebalan filter seperti pada Gambar 10.

Fenomena umum yang dilihat dari grafik penentuan ketebalan filter dengan dosis PAC 0,5 - 3,0 ppm nampak penurunan TDS hampir sama, jika diinginkan penurunan
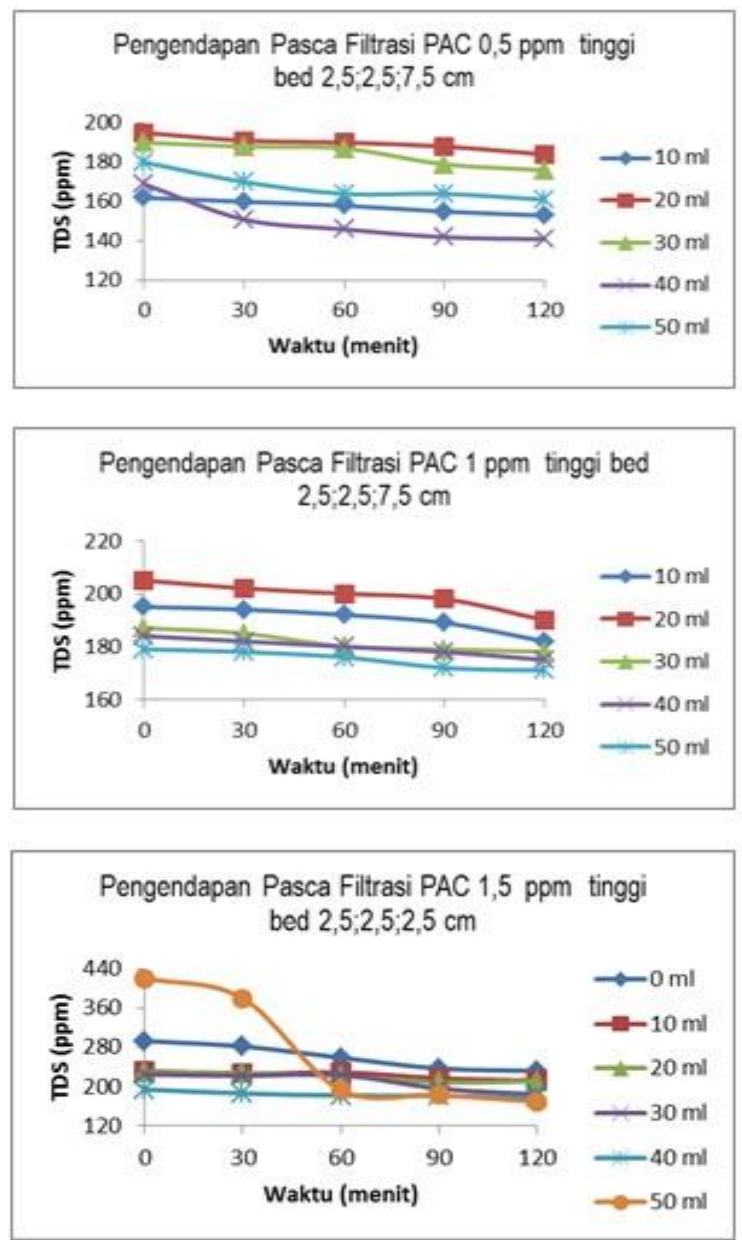

signifikan diperlukan ketebalan filter zeolit yang semakin tebal, serta waktu yang semakin lama. Berdasarkan karakter dosis PAC yang disajikan dalam grafik diatas maka ketebalan optimum penggunaan filter zeolit pada ukuran 2,5 cm koral; 2,5 cm zeolit sedang dan 7,5 cm zeolit halus yang dapat menurunkan TDS sampai dibawah 160 ppm pada penggunaan PAC 0,5 ppm, dalam waktu 30 menit.
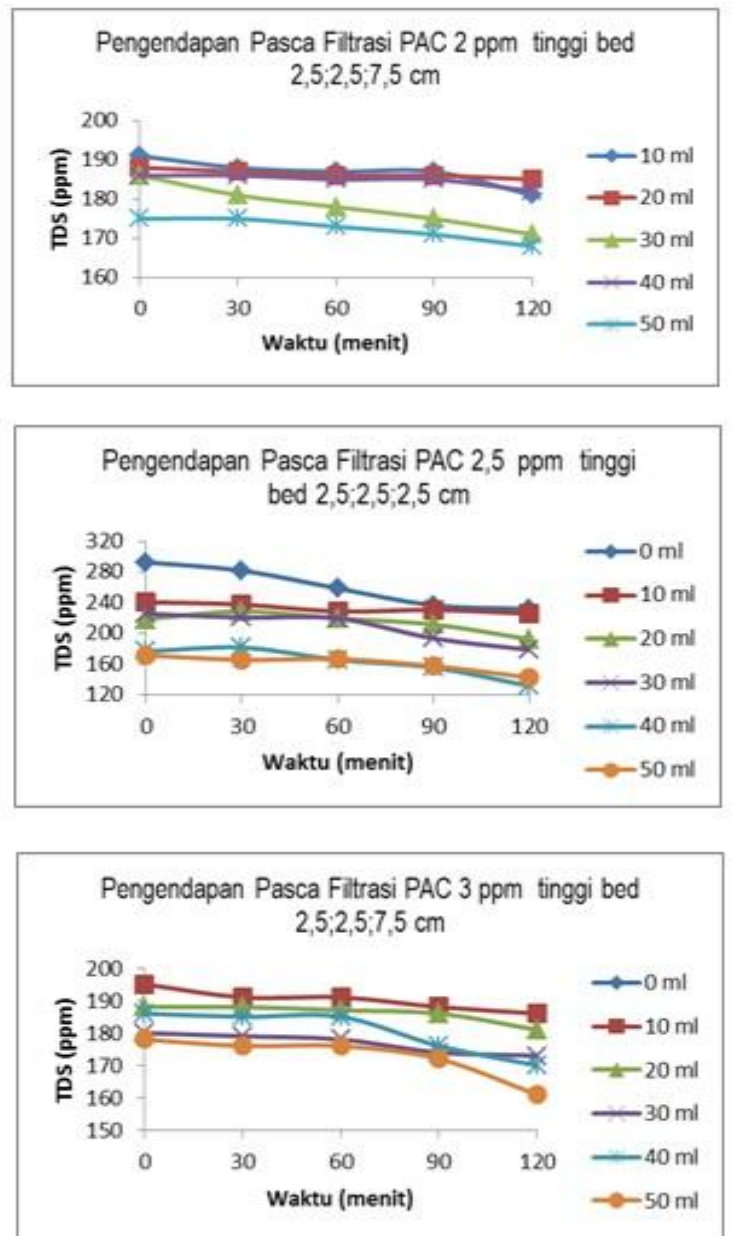

Gambar 10. Penentuan tinggi optimum bed filter zeolite terhadap dosis PAC dengan parameter TDS dan Waktu Pengendapan

\section{c. Penentuan ketebalan filter dengan koagulan Biji}

Kelor.

Uji coba laboratorium dalam penggunaan serbuk biji kelor sebagai koagulan, diperoleh hasil uji secara grafis dalam penentuan ketebalan filter pada Gambar 11.

Fenomena umum yang dilihat dari grafik penentuan ketebalan filter dengan dosis serbuk biji kelor 0,5 - 3,0 ppm nampak penurunan TDS hampir sama, jika diinginkan penurunan signifikan diperlukan ketebalan filter zeolit yang semakin tebal, serta waktu yang semakin lama. Berdasarkan karakter dosis serbuk biji kelor yang disajikan dalam grafik diatas maka ketebalan optimum penggunaan filter zeolit pada ukuran $2,5 \mathrm{~cm}$ koral; $2,5 \mathrm{~cm}$ zeolit sedang dan $7,5 \mathrm{~cm}$ zeolit halus yang dapat menurunkan TDS sampai dibawah 160 ppm pada penggunaan serbuk biji kelor 0,5 ppm, dalam waktu 30 menit. 
Citasi: Bambang Sugiarto, Suharwanto, 2017, Pengembangan Pemanfaatan Pengolahan Air Dalam Upaya Pemenuhan Kebutuhan Air di Dusun Temuireng, Desa Girisuko, Panggang, Gunungkidul, Eksergi, 14(2), 40-52
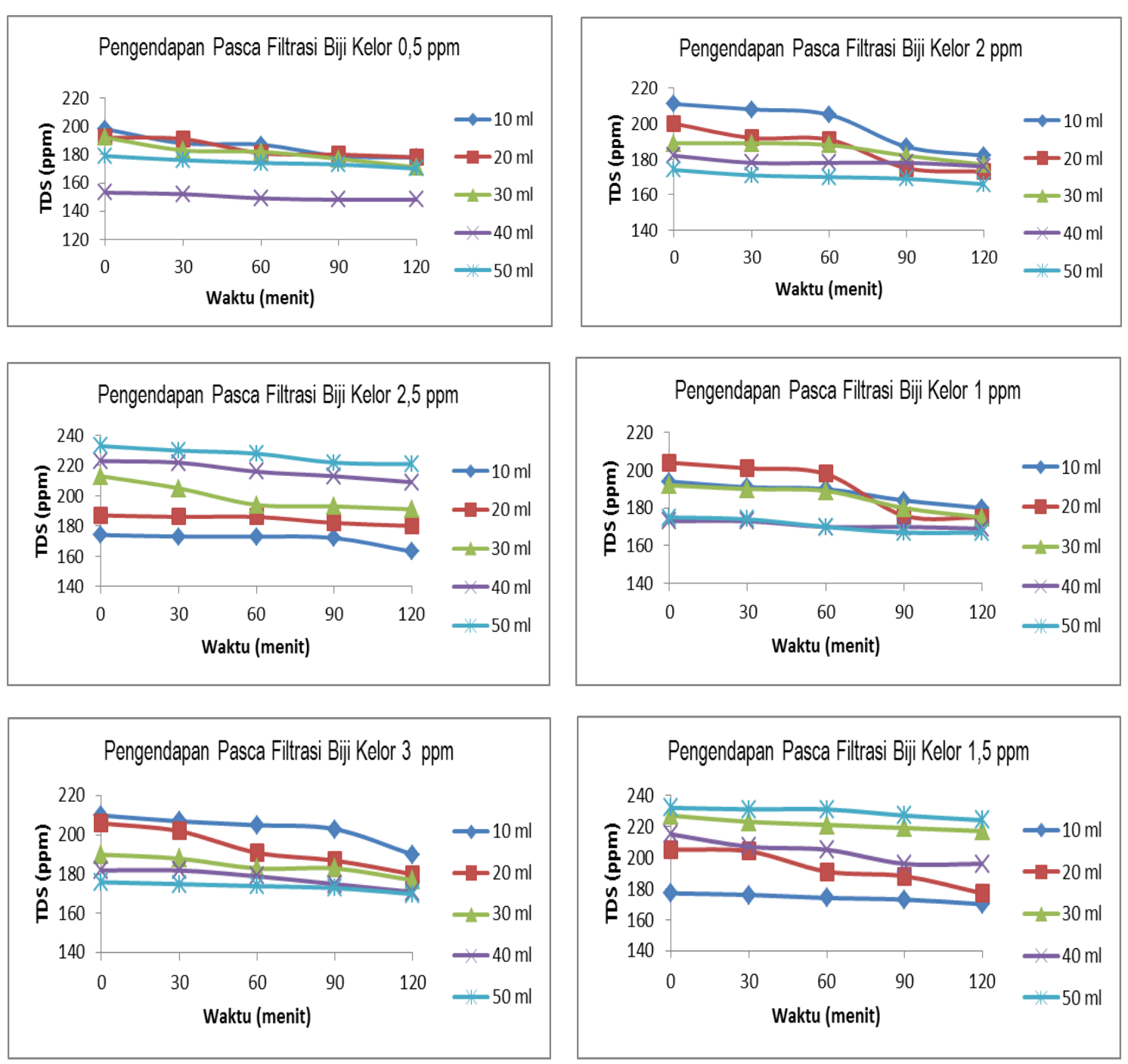

Gambar 11. Penentuan tinggi optimum bed filter zeolite terhadap dosis serbuk biji kelor dengan parameter TDS dan Waktu Pengendapan

\subsection{Simulasi carbon filter}

Dalam biji kelor terdapat senyawa yang menyebabkan rasa air berubah menjadi berasa pahit, sehingga diperlukan perlakuan tambahan yaitu dengan penggunaan carbon filter untuk menetralkan perubahan rasa air tersebut. Untuk itu diperlukan ketebalan carbon filter yang optimum.

Hasil uji penentuan ketebalan arang aktif untuk penggunaan serbuk biji kelor sebagai koagulan, diperoleh hasil uji secara grafis pada Gambar 12.

Fenomena umum yang dilihat dari grafik penentuan ketebalan filter karbon dengan dosis serbuk biji kelor 0,5 - 3,0 ppm nampak penurunan TDS hampir sama, jika diinginkan penurunan signifikan diperlukan ketebalan filter karbon yang semakin tebal, serta waktu yang semakin lama. Berdasarkan karakter dosis serbuk biji kelor yang disajikan dalam grafik diatas maka ketebalan optimum penggunaan filter karbon adalah $7,5 \mathrm{~cm}$ yang dapat menurunkan TDS sampai dibawah 160 - 110 ppm pada penggunaan serbuk biji kelor 0,5 ppm, dalam waktu 30 - 60 menit

\section{Penentuan Sistem Pengolahan Air Minum}

\section{Sistem Filter}

Filtrasi ikut berperanan dalam menentukan kualitas produk, dimana unit filter berfungsi untuk menjerap partikel padat yang belum bisa terpisahkan pada unit flokulasi baik berbentuk flok maupun endapan. Biasanya partikel jenis ini ikut mengalir bersama air olahan akibat gaya apung atau gaya layang dari partikel. Dengan sistem saringan ini diharapkan partikel tersebut dapat ditangkap/dijerap. Untuk itu dirancang sistem filter sebagaimana diilustrasikan dalam Gambar 13.

\section{Sistem Distilasi Percik}

Lokasi SPAM banyak terkena sinar matahari, dimana mulai pukul 08.00- 16.00 WIB menerima intensitas sinar 
matahari yang cukup tinggi, sehingga dapat dimanfaatkan untuk proses desalinasi menggunakan tenaga surya
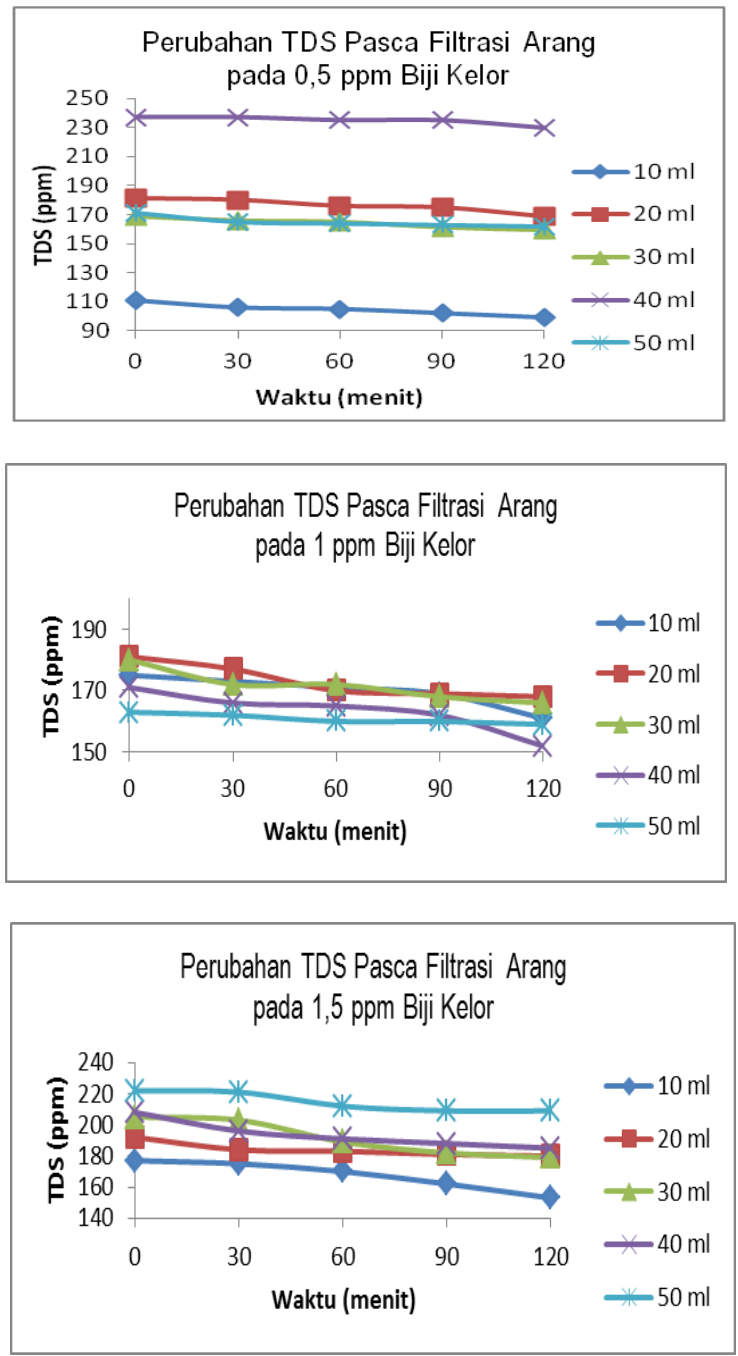

(penguapan). Untuk itu dirancang sistem distilasi percik sebagaimana disajikan dalam Gambar 14.
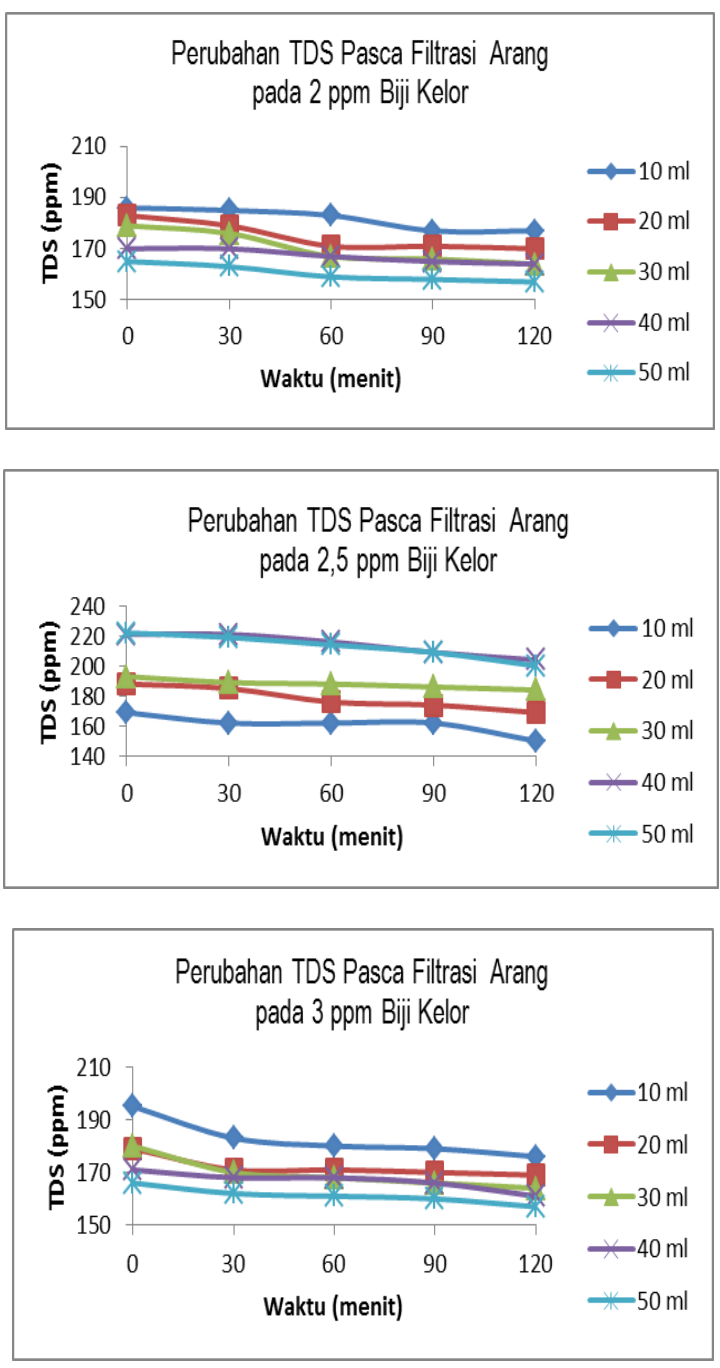

Gambar 12. Penentuan tinggi optimum filter karbon terhadap dosis serbuk biji kelor dengan parameter TDS dan Waktu Pengendapan
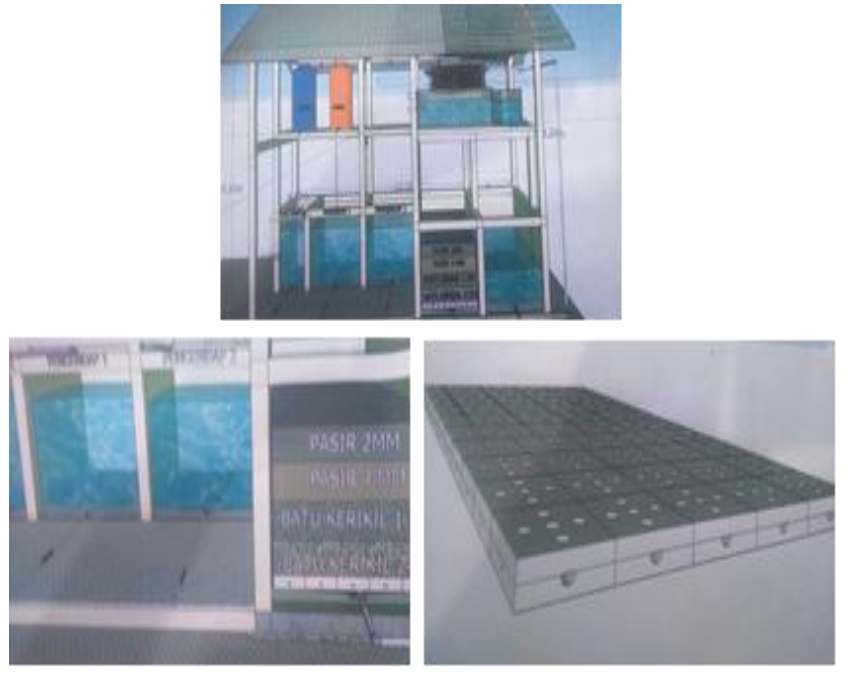

Gambar 13. Penentuan Sistem Filter pada SPAM Temuireng 


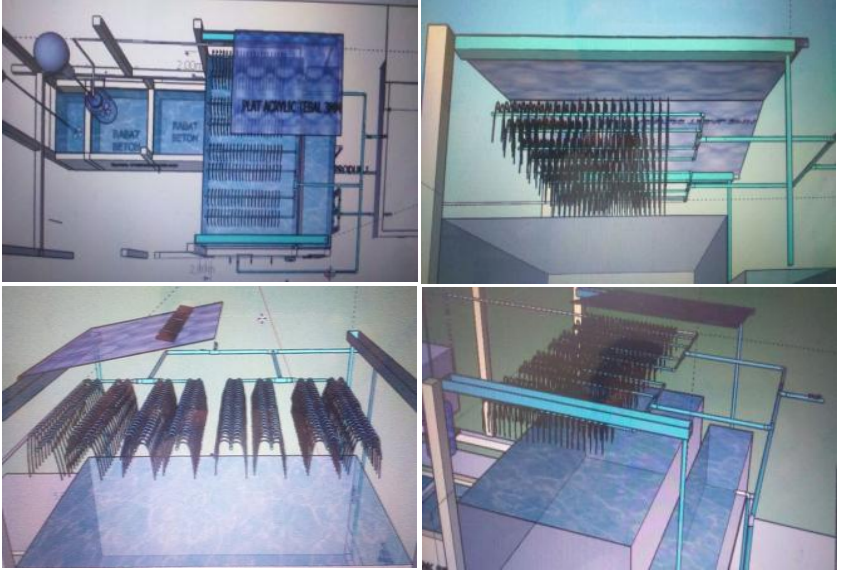

Gambar 14. Penentuan Model Distilasi Percik pada SPAM Temuireng

\section{Kesimpulan}

Kualitas air baku dimusim pada curah hujan tinggi yang berasal dari Baron maupun gua Ngobaran dengan TDS yang tinggi sekitar 400 ppm dan bakteri E. coli 9000 per $100 \mathrm{ml}$ sedang total bakteri Coliform 28000 per $100 \mathrm{mt}$. Dari analisa air dimusim curah hujan sedang total coliform 4000 per $100 \mathrm{ml}$, dan analisa air dimusim curah hujan rendah (kemarau) total coliform berkisar 400 per $100 \mathrm{ml}$. menurunkan TDS dari kisaran 262-288 ppm menjadi dibawah 200 ppm, dan jika dilanjutkan dengan filtrasi dengan media filter zeolit mampu menurunkan TDS hingga dibawah 180 ppm dalam waktu pengendapan 30 menit. Dan untuk dosis kelor jika dilanjutkan dengan perlakuan filter karbon mampu menurunkan TDS hingga dibawah 160 ppm dalam waktu filtrasi 30-60 menit. Sedang untuk proses olahan dengan destilasi percik tenaga surya, memungkinkan terjadi penurunan TDS maupun coliform namun diperlukan intensitas sinar matahari yang cukup tinggi untuk proses penguapan.

\section{Ucapan Terima kasih}

Ucapan terimakasih, peneliti sampaikan kepada :

1. Allah SWT, atas perkenan, barokah dan IzinNya

2. Direktur PPTI, Kemenristekdikti atas kesempatan dan selaku penyandang dana, sehingga terlaksananya kegiatan ini.

3. Kepala LPPM UPN"Veteran" Yogyakarta, atas arahan, bimbingan dan dukungannya dari saat penyusunan proposal, terlaksananya kegiatan hingga tersusunnya laporan penelitiann ini.

4. Kepala BPPT-B2TKE atas kerjasamanya dalam konsorsium ini

5. Direktur PDAM Tirta Handayani, atas kerjasama dan dukungan moril-materiil dalam konsorsium penelitian ini.

6. Pemerintah Kabupaten Gunung Kidul berserta seluruh Jajarannya dari Sekretaris Daerah hingga Kepala Dusun dan Ketua RT di wilayah Temuireng, atas segala dukungan baik moril dan materiil sehingga terlaksananya kegiatan implementasi dari penelitian ini.

7. Seluruh Tim Penelitian PPTI, dari Dosen, Laboran dan Mahasiswa yang tidak dapat disebutkan satu persatu, atas keterlibatan dan dukungansehingga terlaksananya penelitian ini.

8. Orang Tua, Istri, Keluarga dan handai taulan yang telah memberikan waktu dan pengertian sehingga terlaksananya kegiatan peneitian ini.

\section{Daftar Pustaka}

Adji, T.N., 2005, Agresivitas Airtanah Karst Sungai Bawah Tanah Bribin, Gunungsewu, Indonesia Cave and Karst Journal, vol 1 No 1, HIKESPI.

Anonim, 2010 , Peraturan Menteri Kesehatan No 492/ MENKES/ PER/ IV/2010 Tentang Persyaratan Kualitas Air Minum.

Ausland, G., Stevik, T.K., Hansen, J.F.Kohler, J.C., Jensen, P.D. 2002, Intermittent Filtration of WastewaterRemoval PF Fecal Coliforms And Fecal Streptococci. Water Research 36.

Badingah, 2013, Laporan Status Lingkungan Hidup Daerah Kabupaten Gunung Kidul, Pemerintah Kabupaten Gunung Kidul Daerah Istimewa Yogyakarta

Benefield, ETAC, 1982, "Process Chemistry for Water and Waste Treatment”, Mc Graw Hill Book Co., Inc., New York

Effendi, H. 2003, Telaah Kualitas Air Bagi Pengelolaan Sumber Daya dan Lingkungan Perairan. Cetakan ke lima. Yogyakarta:Kanisius.

Evani, F.S. 2004, Gua Bribin akan atasi kekurangan air gunungkidul,

http://www.suarapembaruan.com/News/2004/2008/08/ 03/Nusantar/Nusa04.htm, Last accessed 22 april 2010.

Foerd, D. and William, P., 1992 Karst Geomorphology and Hydrology, Chapan and Hall, London.

Haryono, E., Adji T., N., 2004 Pengantar Geomorfologi dan Hidrologi Karst, Kelompok Studi Karst, Fakultas Geografi, UGM, Yogyakarta.

Jack Broughton, "Process Utility Sistem, Introduction to Design Operation and Maintenance" Institution of Chemical Engineers, 1994

Kurita , 1980 "Industrial Water Treatment”, Kurita Publ. \& Co, Tokyo

Nugraha, M.P.H., 2016, Kajian Kualitas Air Sungai Bawah Tanah Pada Daerah Imbuhan Dan Daerah Pengolahan Air Goa Bribin, Kabupaten Gunungkidul, Daerah Istimewa Yogyakarta.

Reynolds, T.D, 1982, “ Unit Operations and Process Environmental Engineering", Texas \& M. University, PWS Publishers is a division of Wadswoath. Inc., California

Sanks, 1980, "Water Treatment Plant Design" Science Publisher, New York. 
Tessa, 2017, "Arahan Teknik Pengelolaan Kualitas dan Kuantitas Sungai Bawah Tanah pada Kawasan Karst di Desa Kanigoro, Kecamatan saptosari, Kabupaten Gunungkidul." Skripsi Jurusan Teknik Lingkungan, UPN "Veteran" Yogyakarta.
Wirosarjono, S. 1974. Masalah-masalah yang dihadapi dalam penyusunan kriteria kualitas air guna berbagai peruntukan. PPMKL-DKI Jaya, Seminar Pengelolaan Sumber Daya Air. , eds. Lembaga Ekologi UNPAD. Bandung, 27 - 29 Maret 1974, hal 9-15 